\title{
Modulation of hydrolytic profiles of cell-bound and cell-free exoenzymes in Antarctic marine bacterial isolates
}

\author{
Vincenzo Manna, ${ }^{1,2}$ Paola Del Negro, ${ }^{1}$ Mauro Celussi ${ }^{1 *}$ \\ ${ }^{1}$ Oceanography Division, National Institute of Oceanography and Applied Geophysics (OGS), Via Auguste Piccard 54, 34151 Trieste; \\ ${ }^{2}$ Department of Life Sciences, University of Trieste, Via Licio Giorgieri 5, 34127 Trieste, Italy
}

\begin{abstract}
Microbial degradation of high molecular weight organic matter in the marine environment is dependent on the synthesis and activity of hydrolytic exoenzymes. These can be found both associated to the cell (i.e., attached to cell-wall or in the periplasmic space) and cell-free, dissolved in the surrounding waters. Recent evidences suggest that exoenzymes location is linked to different foraging strategies. 'Selfish' bacteria use cell-bound enzymes to obtain large oligomers which are then further degraded in the confined periplasmic space, whereas cell-free enzymes are thought to be advantageous for particle-attached prokaryotes, consequently 'sharing' the hydrolysis product with other members of the degrading consortium. We examined whether different bacterial isolates exhibit different exoenzymatic activity profiles when exposed to different growth condition. Seven bacterial strains, isolated from the Ross Sea, were screened for the production of $\beta$-glucosidase, alkaline-phosphatase, lipase, chitinase and leucine aminopeptidase, assaying the hydrolysis rates of both cell-bound and cell-free exoenzymatic fractions. Furthermore, to test whether bacteria growing on particles are more prone to produce cell-free exoenzymes, we set up a controlled experiment, amending one of the bacterial isolates with phytodetritus, in order to promote the colonization of aggregates. Cell specific hydrolytic rates were highly variable and different isolates expressed different dominant hydrolytic activities. These results demonstrate a specialization for different substrates in different bacteria, further suggesting that some of the tested isolates may have an intrinsic potential to copiously produce cellfree exoenzymes. Moreover, our results suggest that this specialization is not strictly genetically determined but varies according to growth conditions. The experiment performed with phytodetrital particles highlighted an increasing contribution of the dissolved exoenzymatic activity in samples bearing aggregates and associated bacteria. Also, the tested isolate further modulated its hydrolytic machinery, expressing a different enzymatic profile when exposed to phytodetrital particles. The continuation of these experimental activities, testing the response of different bacterial isolates to different substrates, will help to determine the conditions under which different hydrolysis patterns develop, deepening the current knowledge on the organic matter cycling in the ocean.
\end{abstract}

\section{INTRODUCTION}

Microorganisms play a pivotal role in the marine carbon cycle (Azam and Malfatti, 2007), by producing, processing and utilizing one of the largest pools of active C-containing molecules on Earth (Hansell et al., 2009). In order to obtain the energy and carbon source required for growth, microbes utilize preferentially high-molecular weight substrates, as they are more bioavailable, according to the size-reactivity model (Benner and Amon, 2015). However, only small molecules can be taken up by the cells and therefore extracellular hydrolysis is a vital process for prokaryotic heterotrophs (reviewed by Arnosti, 2011). In fact, measurable organic matter degradation rates have been found in all marine environments where life is possible, from deep subsurface sediments (Hoarfrost et al., 2017) through the water column (Hoppe and Ullrich, 1999; Celussi et al., 2018), to sea spray aerosol particles ejected to the atmosphere (Malfatti et al., 2019), form the equator to the poles (Misic et al., 2006; Celussi et al., 2009). Due to the wide array of environmental conditions (e.g. temperature, salinity, $\mathrm{pH}$, pressure) where microorganisms thrive and produce active hydrolytic enzymes, such proteins harbor the potential for extensive utilization in biotechnological and industrial applications (Nigam, 2013).
Specialized prokaryotes invest their energy efforts into the degradation of specific complex substrates (e.g. hydrocarbons, plastics; Hassanshahian et al., 2014; Yoshida et al., 2016) whereas generalists harbor the potential for hydrolyzing a wide array of macromolecules (Martinez et al., 1996). Another strategy is dependent on the location of exoenzymes with respect to the producing cell. In fact, exoenzymes can be cell-associated (i.e. attached to the cell wall or in the periplasmic space) or released (i.e. cellfree) in the surrounding waters (Hoppe et al., 2002), thus identifying selfish $v s$ 'social' foragers (Traving et al., 2015). In the former case, after the uptake of large oligomers, further degradation occurs in the protected periplasmic space, avoiding diffusive loss of target monomers and enzymes (Reintjes et al., 2017). In the latter case the release of enzymes is thought to be beneficial for microorganisms living attached to particles or colloids, where different cells can take advantage of specific degradation products made available by other consortium members in diffusionally constrained microenvironments (Vetter et al., 1998). Within this scheme Reintjes et al. (2019) recently included the category of 'scavengers', defined as microbes that do not produce specific exoenzymes and take advantage of the 'public goods' made available by other cells. Much attention has lately been addressed to cell-free enzymes, since they may not be strictly dependent on the metabolism of microbes, but 
their presence could also be a consequence of the history and dynamics of the water masses, due to their potential long-term persistence in the environment (Baltar et al., 2013). Within this framework we aimed at characterizing the degradative potential of several bacterial isolates and, by utilizing one of these model organisms, providing a proof of concept on the differential production of cell-free enzymes by particle-attached microbes, if compared to their free-living counterparts.

We chose a set of bacteria isolated from several locations and depth in the Ross Sea (Antarctica) for two main reasons. The first, of ecological nature, is related to the high summer productivity of the Ross Sea. Indeed, in this system the export of particulate organic carbon (POC) to the mesopelagic is approximately $40-50 \%$ of the surface primary production (Catalano et al., 2010), compared to a global estimate ranging from 1 to $40 \%$ (Ducklow et al., 2001). Since the fate of sinking POC is highly dependent on its mineralization by prokaryotes $(>70 \%$ of the total loss during export; Giering et al., 2014) we envisioned to obtain model organisms (bacterial isolates) and model particles (Antarctic phytodetritus) to deepen the current knowledge on POC degradation and POC-bacteria interactions. The second reason is to be related to the biotechnological potential of bacteria isolated in extreme environments. Due to the limited accessibility of these systems, the current knowledge on the bioactive molecules and secondary metabolites produced by extremophiles is extremely limited (Lo Giudice and Fani, 2015), opening inestimable chances for novel discoveries.

\section{METHODS}

\section{Bacterial isolation}

The bacterial strains used for the experimental activities were isolated from water samples collected in austral summer 2006 and 2017. Seawater was sampled at several locations and depths in the Ross Sea (Tab. 1) by means of 12-L Niskin bottles mounted on an SBE 32 carousel sampler. Seawater aliquots were collected in sterile $50-\mathrm{mL}$ tubes, plated onto ZoBell 2216 agar plates and kept at $4^{\circ} \mathrm{C}$. Bacterial colonies with different morphologies were selected and purified by serial streaking on the same medium for a minimum of four times. A total of 22 isolates (4 from 2006 and 18 from 2017 cruises) were maintained both in solid ZoBell 2216 agar plates and liquid ZoBell Marine Broth in the dark at 4 and $10^{\circ} \mathrm{C}$, respectively. All the experimental activities described in this study were carried out between October and November 2018.

\section{Bacterial identification}

From each isolate DNA was extracted by means of the DNeasy Tissue Kit (Qiagen) according to the supplier's

Tab. 1. Details of sampling stations (coordinates, depth and location) in the Ross Sea and identifier of the strain isolated from each sample. Isolates used for experimental activities are highlighted in bold.

\begin{tabular}{|c|c|c|c|c|c|}
\hline Isolate ID & Latitude ( $\left.{ }^{\circ} \mathbf{S}\right)$ & Longitude $\left({ }^{\circ} \mathbf{E}\right)$ & Depth (m) & Date & Location \\
\hline $\mathbf{A F}$ & 74.9400 & -176.2432 & 400 & $23 / 01 / 2006$ & Glomar Challenger basin, core of Circumpolar Deep Water \\
\hline AG & 74.9400 & -176.2432 & 400 & 23/01/2006 & Glomar Challenger basin, core of Circumpolar Deep Water \\
\hline AK & 74.9400 & -176.2432 & 400 & $23 / 01 / 2006$ & Glomar Challenger basin, core of Circumpolar Deep Water \\
\hline 9 & 74.7572 & 166.8105 & 910 & $23 / 01 / 2017$ & Drygalki Basin, bottom layer \\
\hline $9+1$ & 74.7572 & 166.8105 & 910 & $23 / 01 / 2017$ & Drygalki Basin, bottom layer \\
\hline 9 _2 & 74.7572 & 166.8105 & 910 & 23/01/2017 & Drygalki Basin, bottom layer \\
\hline $14 \_1$ & 74.7572 & 166.8105 & 30 & $23 / 01 / 2017$ & Drygalki Basin, deep chlorophyll maximum \\
\hline $14 \_2$ & 74.7572 & 166.8105 & 30 & $23 / 01 / 2017$ & Drygalki Basin, deep chlorophyll maximum \\
\hline $14 \_3$ & 74.7572 & 166.8105 & 30 & $23 / 01 / 2017$ & Drygalki Basin, deep chlorophyll maximum \\
\hline 15 & 74.7572 & 166.8105 & 5 & $23 / 01 / 2017$ & Drygalki Basin, surface layer \\
\hline $16 \_1$ & 74.0000 & 175.089 & 572 & $17 / 01 / 2017$ & Joides basin, bottom layer \\
\hline 16_1_1 & 74.0000 & 175.089 & 572 & 17/01/2017 & Joides basin, bottom layer \\
\hline $16 \_1 \_2$ & 74.0000 & 175.089 & 572 & $17 / 01 / 2017$ & Joides basin, bottom layer \\
\hline 16_1_3 & 74.0000 & 175.089 & 572 & $17 / 01 / 2017$ & Joides basin, bottom layer \\
\hline $16 \_1 \_4$ & 74.0000 & 175.089 & 572 & $17 / 01 / 2017$ & Joides basin, bottom layer \\
\hline $16 \_1 \leq 5$ & 74.0000 & 175.089 & 572 & $17 / 01 / 2017$ & Joides basin, bottom layer \\
\hline $16 \_2$ & 74.0000 & 175.089 & 572 & $17 / 01 / 2017$ & Joides basin, bottom layer \\
\hline 20_1 & 74.0000 & 175.089 & 40 & 17/01/2017 & Joides basin, deep chlorophyll maximum \\
\hline $20 \_2$ & 74.0000 & 175.089 & 40 & $17 / 01 / 2017$ & Joides basin, deep chlorophyll maximum \\
\hline $20 \_3$ & 74.0000 & 175.089 & 40 & $17 / 01 / 2017$ & Joides basin, deep chlorophyll maximum \\
\hline 21 & 74.0000 & 175.089 & 5 & $17 / 01 / 2017$ & Joides basin, surface layer \\
\hline
\end{tabular}


instruction. The amplification of the 16S rRNA gene was performed utilizing the universal primer $27 \mathrm{~F}$ and the Eubacterial primer 1492R as detailed in Celussi et al. (2008). PCR products were purified using the QIAquick PCR purification kit (Qiagen) according to the supplier's instruction and amplicons were sequenced using ABI Prism Big Dye-terminator chemistry at the 'BMR Genomics' facility at the University of Padova (www.bmr-genomics.it). Sequences were aligned to known sequences in the GenBank database using BLAST (Altschul et al., 1990). Multiple sequence alignment was performed using the SINA aligner (http://www.arb-silva.de/aligner/) and compared to the SILVA reference database release 111 (Quast et al., 2013). Phylogenetic tree was built using the Phylogeny.fr (https://www.phylogeny.fr/; Dereeper et al., 2008) tool, visualized and annotated with Interactive Tree Of Life (iTOL, v3; Letunic and Bork, 2016). The identical nucleotide sequence of several bacterial isolates led us to select 7 of them, out of the original 22 , for the subsequent activities. The nucleotide sequences obtained in this study are deposited in GenBank under the accession numbers MK780011-MK780031.

\section{Exoenzymatic fingerprinting}

The selected isolates were transferred in a ZoBell Marine Broth diluted 5 times $(\mathrm{ZB} / 5)$ in $0.2 \mu \mathrm{m}$-filtered and autoclaved $\left(121^{\circ} \mathrm{C}\right.$ for $\left.15 \mathrm{~min}\right)$ seawater (FASW) collected in the northern Adriatic Sea, and incubated at $0^{\circ} \mathrm{C}$. After 2 days of acclimation at the experimental temperature, the isolates were inoculated in duplicate $100 \mathrm{~mL}$ aliquots of $\mathrm{ZB} / 5$ at a starting abundance of $10^{8}$ cell $\mathrm{L}^{-1}$ $\left(\mathrm{d}_{0}\right)$. Cell numbers were determined by flow cytometry according to the method described by Marie et al. (1999). A FACSCanto II (Becton Dickinson, Franklin Lakes, NJ, USA) instrument was used, equipped with an air-cooled laser at $488 \mathrm{~nm}$ and standard filter setup. Samples $(0.5$ $\mathrm{mL}$ ) were ultrasonicated (10 cycles of $30 \mathrm{~s}$ on-off) and fixed with $0.5 \%$ (final concentration) glutaraldehyde (Grade I for EM analyses; Sigma Aldrich, St. Louis, MO, USA). Fixed samples were kept at $4{ }^{\circ} \mathrm{C}$ for $15 \mathrm{~min}$ and diluted 1:10 with $0.2 \mu \mathrm{m}$-filtered Tris-EDTA buffer $1 \mathrm{X}$ (Sigma Aldrich). Samples were then stained with SYBR Green I nucleic acid dye (Life Technologies, Carlsbad, CA, USA) at $1 \times 10^{-4}$ dilution of the commercial stock and incubated for 10 minutes in the dark at room temperature. Data were acquired using green fluorescence as trigger and processed with the FACSDiva software (Becton Dickinson). The flow rate was calibrated daily, by running distilled water and weighing it before and after the run (at least 5 replicates). Abundances were then calculated using the acquired cell counts and the respective flow rates.

Bacterial abundance was estimated every 2 days by means of flow cytometry, as described above. When the growth curves evidenced the exponential growth phase, 50$\mathrm{mL}$ of the cultures were washed twice in FASW by centrifuging at $3200 \times g$ for $10 \mathrm{~min}$ at $0^{\circ} \mathrm{C}$. This procedure was aimed at transferring the isolates in a 'poorer' medium (1.48 $\mathrm{mg} \mathrm{L}^{-1}$ of dissolved organic carbon; F. Relitti, personal communication) and allowed the removal of hydrolytic enzymes in the dissolved phase. Immediately after the washing with FASW, exoenzymatic activities (EEAs) were measured $\left(\mathrm{d}_{\text {exp }}\right)$. The activities of beta-glucosidase (BGLU), alkaline phosphatase (AP), lipase (LIP), chitinase (CHIT) and leucine aminopeptidase (AMA) were estimated by the artificial fluorogenic substrate analogue method (Hoppe, 1993). Artificial substrates were added to $2 \mathrm{~mL}$ of the isolates in FASW in triplicate, at saturating concentrations. BGLU, AP, LIP, CHIT and AMA were determined after the addition of 4-methylumbelliferone- $\beta$-D-glucoside (200 $\mu \mathrm{M})$, 4-methylumbelliferone-phosphate $(50 \mu \mathrm{M})$, 4-methylumbelliferone -oleate $(100 \mu \mathrm{M})$, 4-methylumbelliferone $N$-acetyl- $\beta$-D-glucosaminide $(200 \mu \mathrm{M})$ and leucine-7amino-methyl-coumarine $(200 \mu \mathrm{M})$, respectively. All samples were incubated in the dark at $0^{\circ} \mathrm{C}$ for $3 \mathrm{~h}$. Enzyme activities were derived from the increase in fluorescence due to the cleavage of the artificial substrate, measured with a Shimadzu RF1501 fluorometer at $365 \mathrm{~nm}$ excitation / 455 emission for BGLU, AP, LIP and CHIT and $380 \mathrm{~nm}$ excitation / 440 emission for AMA. Calibration curves were performed at each working session utilizing FASW and standard fluorochrome solutions $(5 \mu \mathrm{M})$. The substrates and the standards were purchased from Sigma-Aldrich. The same procedure was performed on $0.2-\mu \mathrm{m}$-filtered subsamples to measure the activity of dissolved exoenzymes, that, as expected, was not detectable at this stage. The remaining volume of the cultures in FASW was incubated at $0^{\circ} \mathrm{C}$ for a number of days equal to the one necessary for bacteria to grow exponentially, as observed earlier during the experiment (i.e. from $\mathrm{d}_{0}$ to $\mathrm{d}_{\text {exp }}$, between 4 and 8 days, depending on the isolate). At the end of this incubation $\left(\mathrm{d}_{\mathrm{fin}}\right)$ EEA measurements and cell counts were performed a second time.

The hydrolysis rates (normalised per cell numbers) measured in the two time points $\left(\mathrm{d}_{\exp }\right.$ and $\left.\mathrm{d}_{\text {fin }}\right)$ were then analysed with an nMDS. The simultaneous analysis of several metabolic features (e.g. the degradation and/or utilization of specific substrates) provides useful information on the functional changes that microbes undergo in different culturing conditions and allows to visualize changes in the enzymatic profiles (Celussi et al., 2008; Del Negro et al., 2018). The nMDS was performed using a Bray-Curtis dissimilarity matrix, built with log-transformed $(\ln (x+1))$ isolates' hydrolysis rates. Analysis of similarity (ANOSIM, Clarke and Warwick, 1994) was used to test the significance of samples grouping on the nMDS plot. nMDS and ANOSIM were carried out using the R package vegan (Oksanen et al., 2018), under R 3.5.1 (R Development Core Team, 2018). 


\section{Exoenzymatic activities on phytodetrital particles}

In order to test whether bacteria growing on particles are more prone to produce cell-free (dissolved) exoenzymes, a second experiment was set up. The phytodetritus (particles) was generated from a microplankton net sample $(20 \mu \mathrm{m}$ mesh-size) collected in the Ross Sea $\left(74.7572^{\circ} \mathrm{S} ; 166.8105^{\circ} \mathrm{E}\right)$ on January $23^{\text {rd }}, 2017$ in the upper $100 \mathrm{~m}$ of the water column. Chlorophyll $a$ concentration in the net sample was measured by the standard fluorometric procedure (Lorenzen and Jeffrey, 1980). The identification of microplanktonic organisms in the sample was carried out on a fixed aliquot (formaldehyde solution, $4 \%$ f.c.) at the inverted microscope (Labovert FS Leitz) equipped with phase contrast at a magnification of 400x and 630x, according to the Utermöhl method (Utermöhl, 1958). The net sample was subjected to 7 cycles of freezethawing $\left(-80^{\circ} \mathrm{C} /+80^{\circ} \mathrm{C}\right.$, Bidle and Azam, 1999) after which cells were pelleted $(20,000 \times g, 10 \mathrm{~min}$, room temperature) and the supernatant (organic carbon in the dissolved phase) removed. Cells were then resuspended in an equal volume of FASW.

Four 50-mL tubes containing FASW with $10^{8}$ cell L-1 of the fast-growing isolate $\mathrm{AG}$ were amended with a volume of detritus to yield a concentration of $10 \mu \mathrm{g}$ of chlorophyll $\mathrm{a} \mathrm{L}^{-1}$, so as to simulate the particulate organic matter content during a phytoplankton bloom. The tubes were kept in a temperature-controlled circulating-water-bath at $10^{\circ} \mathrm{C}$ for $24 \mathrm{~h}$ to promote the colonization of particles by bacteria. After this step, the tubes were kept standing at the same temperature for additional $24 \mathrm{~h}$ to allow the settlement of particles at the bottom (Martinez et al., 1996). Afterwards, the upper $47 \mathrm{~mL}$ within the tubes, potentially bearing only freeliving bacteria and dissolved exoenzymes, were carefully transferred to a new sterile $50-\mathrm{mL}$ tube and the remaining 3 $\mathrm{mL}$ (potentially bearing only particles and particle-attached bacteria) were added with FASW to a final volume of 50 $\mathrm{mL}$. So, at the end of this process, 4 tubes contained particles+attached bacteria (PART) and 4 tubes contained freeliving bacteria and the dissolved fraction of exoenzymes that have been produced in the previous $48 \mathrm{~h}$ (SUR). Half of the tubes were used for testing beta-glucosidase activity and the other half for testing leucine aminopeptidase activity, in experimental duplicates. EEA were measured after 3 and $6 \mathrm{~h}$ (t3 and t6) from the splitting of particles and free-living bacteria, in order to allow the production of cell-free enzymes by particle-attached bacteria. EEA were analysed as described above on the total and $<0.2 \mu \mathrm{m}$ fractions. At $\mathrm{t} 3$ and t6 samples for the enumeration of bacterial cells were collected and fixed with $0.2-\mu \mathrm{m}$ filtered dolomite-buffered formalin ( $2 \%$ f.c.). In this experiment bacteria were counted at the epifluorescence microscope after DAPI staining (as detailed in Celussi et al., 2008) in order to discriminate between free-living and particle-attached cells. In this latter case, the number of cells were multiplied by a factor of 2 to compensate for the non-visible cells attached in the lower side of particles.

\section{RESULTS}

\section{Identification}

Phylogenetic analysis of $16 \mathrm{~S}$ rRNA sequences identified the 22 bacterial isolates as members of the classes Flavobacteriia and $\gamma$-Proteobacteria (Fig. 1). The identical nucleotide sequence of several bacterial isolates led us to select 7 of them (AG, 20_1, 16_1_1,21, 9_2, AK and AF), out of the original 22 , for the subsequent experimental activities.

\section{Exoenzymatic fingerprinting of bacterial isolates}

All the 7 selected isolates were able to produce the assayed exoenzymes (i.e., BGLU, AP, LIP, CHIT and AMA) both at $\mathrm{d}_{\mathrm{exp}}$ and $\mathrm{d}_{\text {fin }}$, with the cell-specific activities of each enzyme varying up to 1 order of magnitude among different isolates (Fig. 2). The enzymatic fingerprints of different isolates were quite variable, both in terms of degradative profiles and of relative contribution of cell-free and cell-bound exoenzymes to the total cell-specific activity.

On the nMDS plot (Fig. 3), bacterial isolates were separated into three groups (ANOSIM R $=0.95, \mathrm{P}=0.001$ ), according to their prevalent exoenzymatic activity. Isolates 21 and 16_1_1 were identified as mostly glycolytic strains (Fig. 3), both at $d_{\text {exp }}$ and $d_{\text {fin }}$ (see section 'Methods'). At $\mathrm{d}_{\mathrm{fin}}$ these isolates showed the highest glycolytic activity among the selected bacterial strains, coupled with an increased contribution of the dissolved exoenzymatic fraction to the total specific activity (up to $100 \%$, Fig. 2). Four out of the seven tested strains were identified as harbouring a high proteolytic potential (20_1, AF, AK, AG; Fig. 3 ), showing the highest AMA specific hydrolysis rates, between $237.34 \pm 1.5$ and $427.29 \pm 16.29 \mathrm{amol} \mathrm{cell}^{-1} \mathrm{~h}^{-1}$ (Fig. 2). The contribution of the dissolved exoenzymatic fraction to the total specific AMA activity was low for all the four 'proteolytic' strains (between 0 and 6\%, Fig. 2). While at $\mathrm{d}_{\text {fin }}$ these strains were all identified as highly proteolytic, AK and AG were characterized by high production of lipases and alkaline phosphatases at the beginning of the experiment $\left(\mathrm{d}_{\mathrm{exp}}\right.$, Fig. 3). This pattern was partly retained also in the at $d_{\text {fin }}$ as AK and AG were the only strains, among the proteolytic ones, to show a relatively higher specific alkaline-phosphatase and lipase activities (Fig. 2). All the strongly proteolytic isolates showed extremely low values of BGLU and CHIT specific activities ( $<2$ and $<1$ amol cell ${ }^{-1} \mathrm{~h}^{-1}$, respectively, Fig. 2).

\section{Exoenzymatic activities on phytodetrital particles}

In SUR tubes used to test BGLU activity (see section 'Methods'), free-living bacterial abundance was 
$1.40 \times 10^{9} \pm 3.21 \times 10^{8}$ cells $\mathrm{L}^{-1}$ at $\mathrm{t} 3$, remaining quite constant after $3 \mathrm{~h}\left(\mathrm{t} 6,1.24 \times 10^{9} \pm 2.09 \times 10^{8}\right.$ cells $\mathrm{L}^{-1}$, Fig. 4a). Particle-attached cells abundance was 2 order of magnitude lower, showing rather constant values at both sampling points $\left(5.58 \times 10^{7} \pm 4.60 \times 10^{7}\right.$ and $6.07 \times 10^{7 \pm 2.42 \times 10^{7}}$ cells $\mathrm{L}^{-1}$ at $\mathrm{t} 3$ and $\mathrm{t} 6$, respectively, Fig. $4 \mathrm{a}$ ). Tubes bearing particles+attached bacteria (PART) were characterized by a higher abundance of particle-attached cells at both sampling points, showing a decreasing trend over time $\left(3.70 \times 10^{8} \pm 1.82 \times 10^{7}\right.$ and $2.41 \times 10^{8} \pm 7.23 \times 10^{7}$ cells $\left.\mathrm{L}^{-1}\right)$. Contrariwise, free-living bacteria increased over time in the PART treatment, from $6.37 \times 10^{8} \pm 5.92 \times 10^{7}$ to $9.85 \times 10^{8} \pm 1.26 \times 10^{7}$ cells $\mathrm{L}^{-1}$ (Fig. $4 \mathrm{a}$ ).

A similar pattern was noticeable in the tubes used for

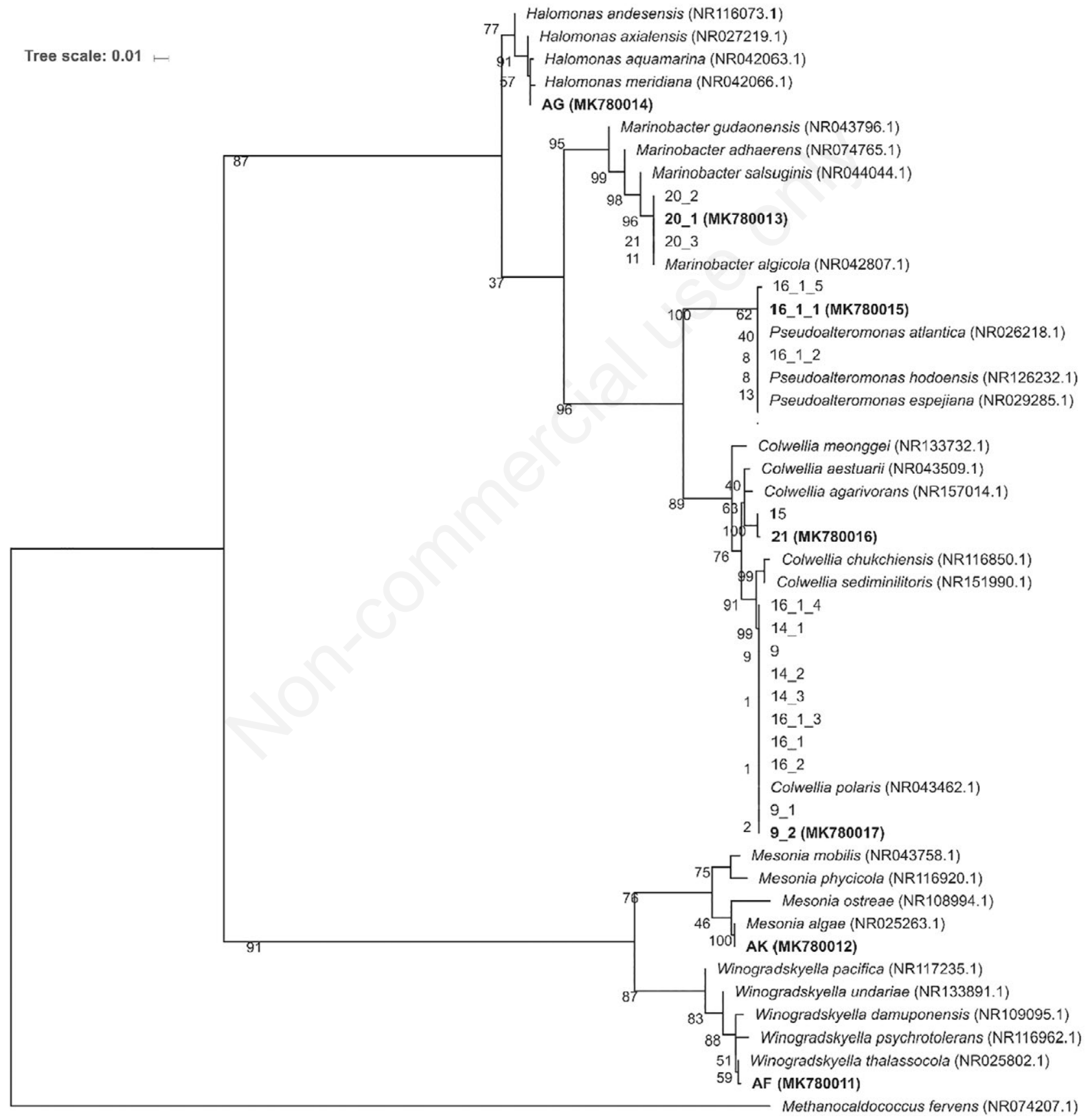

Fig. 1. Neighbour-joining tree based on 16S rRNA gene phylogeny of the 22 bacterial isolates, with Methanocaldococcus fervens as outgroup. GenBank accession numbers are given in parenthesis. Isolates further used for experimental activities are highlighted in bold. The numbers above nodes denote bootstrap values; the scale bar indicates 0.01 changes per nucleotide. 
AMA activity assays (Fig. 4). Free-living bacteria in SUR tubes showed constant abundance between $\mathrm{t} 3$ and $\mathrm{t} 6$ $\left(1.17 \times 10^{9} \pm 1.65 \times 10^{8}\right.$ and $1.26 \times 10^{9} \pm 6.23 \times 10^{7}$ cells $\mathrm{L}^{-1}$, respectively, Fig. $4 \mathrm{~b}$ ) as well as particle-associated cells $\left(6.80 \times 10^{7} \pm 1.83 \times 10^{7}\right.$ and $5.12 \times 10^{7} \pm 8.9 \times 10^{6}$ cells L $^{-1}$, respectively, Fig. 4b). In PART tubes, free-living bacteria increased from $6.08 \times 10^{8} \pm 2.49 \times 10^{7}$ on $t 3$ to $9.14 \times 10^{8} \pm 2.18 \times 10^{7}$ cells $\mathrm{L}^{-1}$ on t6 (Fig. $4 \mathrm{~b}$ ), while particle-attached bacteria abundance declined between sampling times $\left(4.15 \times 10^{8} \pm 1.31 \times 10^{8}\right.$ and $2.31 \times 10^{8} \pm 4.14 \times 10^{7}$ cells $\mathrm{L}^{-1}$, respectively, Fig. 4b).

Results of BGLU and AMA cell-specific hydrolysis rates are reported in Tab. 2. Overall, the cell-free contribution to the total exoenzymatic activity was higher in tubes bearing aggregates and associated bacteria (PART) at both sampling times and for both the exoenzymes tested (Tab. 2). In SUR tubes, specific cell-bound glycolytic activity increased by four-fold between $\mathrm{t} 3$ and t6 $(0.30 \pm 0.05$ and $1.30 \pm 0.47$ amol cell $^{-1} \mathrm{~h}^{-1}$, respectively, Table 2 ), while the activity of the dissolved fraction mildly increased over time (Tab. 2). This pattern resulted in diminished relative contribution of the cell-free to the total exoenzymatic activity, which decreased from $60.83 \pm 1.77$ to $35.32 \pm 3.81 \%$ between t 3 and $\mathrm{t} 6$ (Tab. 2). Tubes bearing aggregates and associated bacteria (PART) were characterized by a higher activity of the dissolved exoenzymatic fraction, which remained quite constant over time $\left(1.11 \pm 0.20\right.$ and $1.01 \pm 0.13 \mathrm{amol} \mathrm{cell}^{-1} \mathrm{~h}^{-}$ ${ }^{1}$ at $\mathrm{t} 3$ and t6, respectively; Tab. 2). Cell-bound specific activity increased from $0.46 \pm 0.08$ to $0.85 \pm 0.03 \mathrm{amol} \mathrm{cell}^{-1} \mathrm{~h}^{-1}$ during the 3 hours incubation, reducing the cell-free pro-

Tab. 2. Cell-specific hydrolysis rates of $\beta$-glucosidase (BGLU) and leucine amino-peptidase (AMA) in amol cell ${ }^{-1} \mathrm{~h}^{-1}$ assayed during the experiment with phytodetrital particles. Results are given as the mean and standard deviation of two experimental replicates.

\begin{tabular}{|c|c|c|c|c|c|c|}
\hline & \multicolumn{3}{|c|}{ t3 } & \multicolumn{3}{|c|}{ t6 } \\
\hline & Cell-bound & Cell-free & $\%$ & Cell-bound & Cell-free & $\%$ \\
\hline BGLU & & & & & & \\
\hline SUR & $0.30 \pm 0.05$ & $0.46 \pm 0.02$ & $60.83 \pm 1.77$ & $1.30 \pm 0.47$ & $0.70 \pm 0.09$ & $35.32 \pm 3.81$ \\
\hline PART & $0.46 \pm 0.08$ & $1.11 \pm 0.20$ & $77.59 \pm 7.50$ & $0.85 \pm 0.03$ & $1.01 \pm 0.13$ & $54.71 \pm 2.42$ \\
\hline AMA & & & & & & \\
\hline SUR & $206.04 \pm 48.83$ & $41.18 \pm 6.26$ & $16.73 \pm 0.77$ & $192.03 \pm 28.12$ & $32.33 \pm 3.26$ & $14.43 \pm 0.35$ \\
\hline PART & $101.32 \pm 3.18$ & $30.54 \pm 1.30$ & $23.18 \pm 1.55$ & $106.67 \pm 5.95$ & $31.20 \pm 1.26$ & $22.67 \pm 1.89$ \\
\hline
\end{tabular}

SUR, tubes with free-living bacteria + dissolved fraction of exoenzymes produced in the previous $48 \mathrm{~h}$; PART, tubes with particles + attached bacteria; Cell-bound, cell-specific hydrolysis rates of cell-attached exoenzymes (total minus cell-free activity); Cell-free, cell specific hydrolysis rates of dissolved exoenzymes (i.e., passing through a $0.2 \mu \mathrm{m}$ filter); \%, relative contribution of cell-free specific hydrolysis rates over the total exoenzymatic activity.
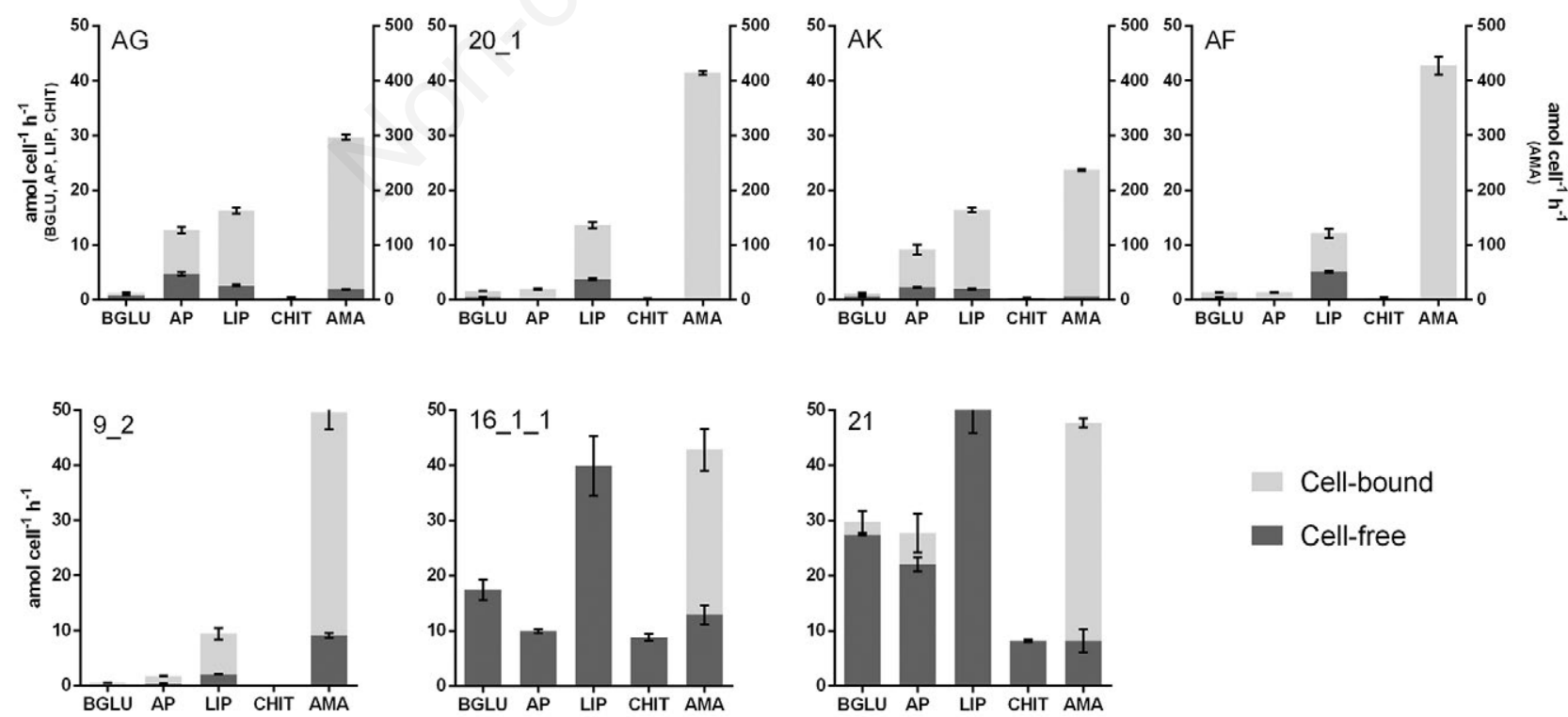

\section{Cell-bound}

Cell-free

Fig. 2. Cell-specific enzyme activities at $d_{\text {fin }}$ of 5 exoenzyme obtained from 7 marine bacteria isolates. On the top row, AMA values are plotted on the right Y-axis. Error bars represent the standard deviation of three analytical replicates. BGLU, $\beta$-glucosidase; AP, alkaline phosphatase; LIP, lipase; CHIT, chitinase; AMA, leucine amino-peptidase. 


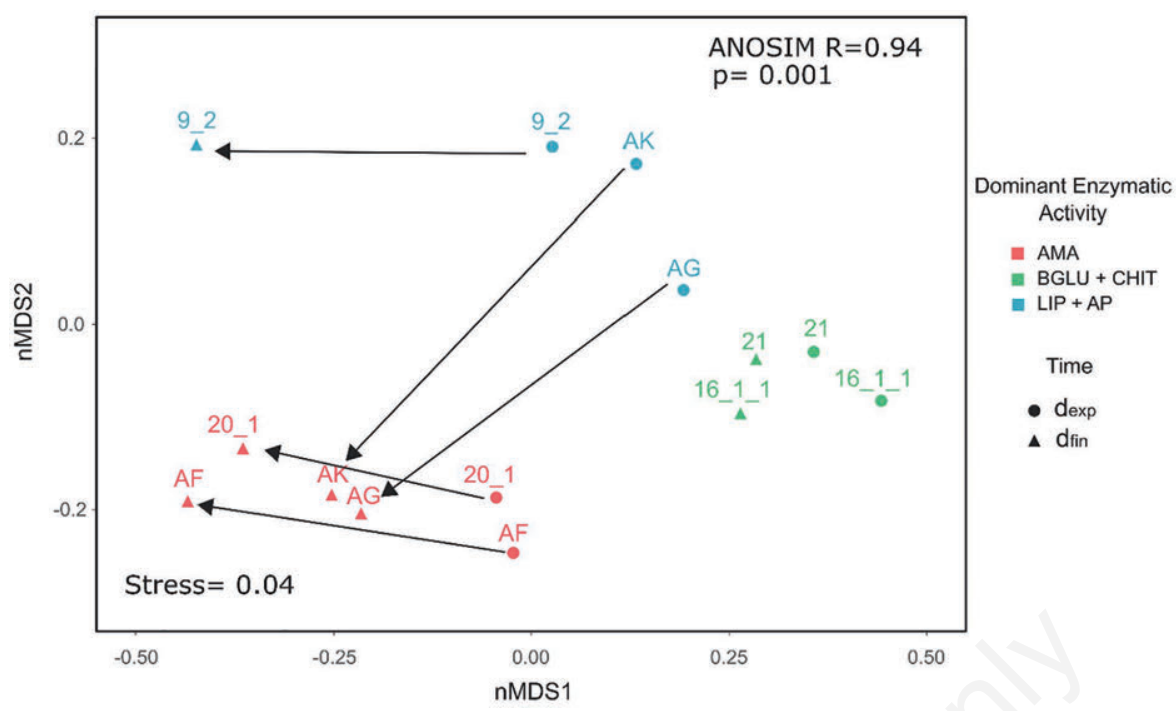

Fig. 3. Non-metric multidimensional scaling (nMDS - 2 dimensional) plot of the selected isolates enzymatic profiles at $d_{\text {exp }}$ and $d_{\text {fin }}$. Arrows highlight the path of the samples between the two experimental conditions. The stress value and the ANOSIM statistics are presented in the lower left and upper right corners, respectively. BGLU, $\beta$-glucosidase; AP, alkaline phosphatase; LIP, lipase; CHIT, chitinase; AMA, leucine amino-peptidase.

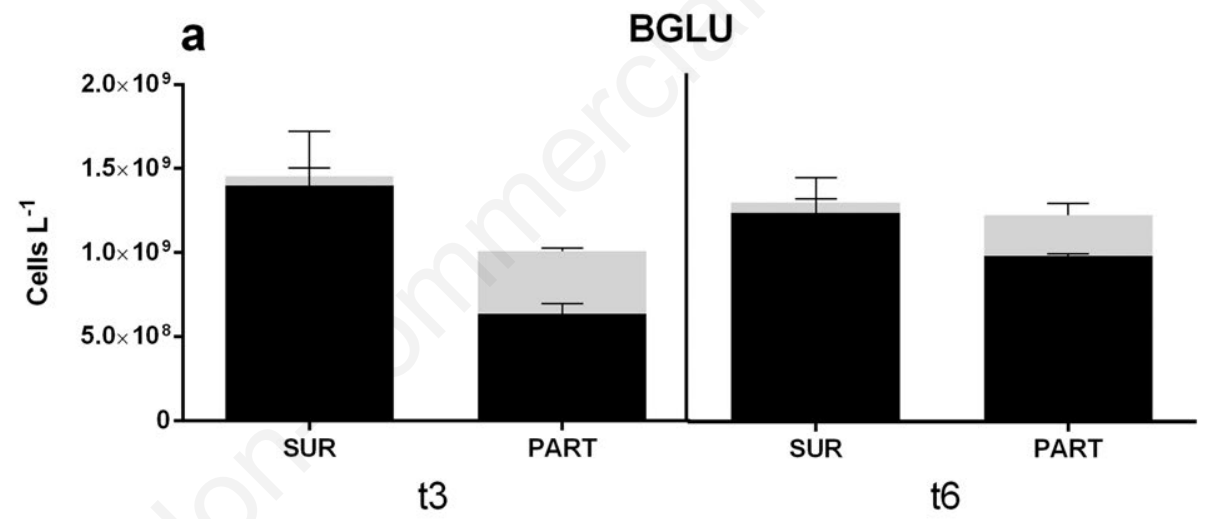

b

AMA

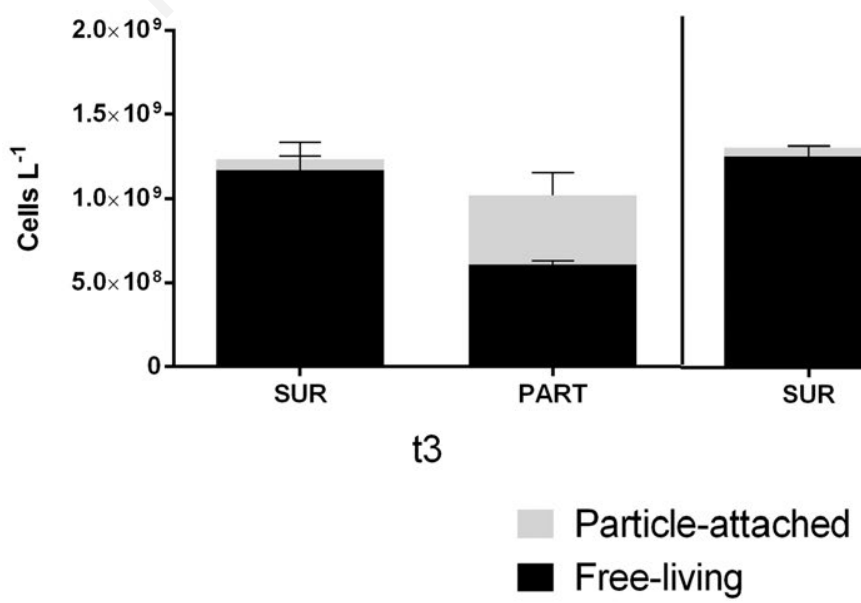

Fig. 4. Bar plots reporting bacterial abundance in the two experimental conditions (SUR and PART) over time, for tubes used to test a) BGLU and b) AMA activities. Error bars represent the standard deviation from the mean of two experimental replicates. 
portion of glycolytic activity from $77.59 \pm 27.50 \%$ at $\mathrm{t} 3$ to $54.71 \pm 2.42 \%$ at t6 (Tab. 2). Protease specific hydrolysis rates were two order of magnitude greater than BGLU activity both in SUR and PART tubes. In samples potentially bearing only free-living microbes, both cell-bound and cellfree exoenzymatic activity decreased over time (Tab. 2), with a rather constant proportion of dissolved to total AMA between $\mathrm{t} 3$ and $\mathrm{t} 6(16.73 \pm 0.77 \%$ and $14.43 \pm 0.35 \%$, respectively; Tab. 2). Over the 3-hours incubation, cell-specific protease activity showed little variation both for cell-bound (101.32 \pm 3.18 and $106.67 \pm 5.95 \mathrm{amol} \mathrm{cell}^{-1} \mathrm{~h}^{-1}$ at $\mathrm{t} 3$ and t6, respectively) and cell-free enzymes (30.54 \pm 1.30 and $31.20 \pm 1.26$ amol cell $^{-1} \mathrm{~h}^{-1}$ at t3 and t6, respectively), resulting in a constant contribution of the dissolved fraction over time (Tab. 2).

\section{DISCUSSION}

In the Ocean, bacteria experience heterogeneous concentrations of organic matter, including hot spots of particulate organic matter (i.e., living and dead phytoplankton cells and marine snow) as well as zones depleted in organic substrates (Stoker, 2012). Therefore, given this extreme variability, the ectohydrolytic profile of a bacterium must reflect a set of strategies to optimize the retrieval of organic substrates from the patchy spatial and temporal distribution of the organic matter in the ocean (Martinez et al., 1996). The enzymatic profile of a single bacterium can thus be viewed as the expression of a peculiar degradative strategy and of its genetic identity, in nature as well as in culture. The bacterial isolates used in this study were grown in the same culture media, yet, notwithstanding the identical growth condition, they expressed a diverse degradative fingerprint. It is worth to point out that during the first experiment, bacteria were transferred from a rich $(\mathrm{ZB} / 5)$ to a poor medium (FASW), and since the enzymatic profiles were tested immediately after the washing of the cultures $\left(\mathrm{d}_{\text {exp }}\right)$, it is very likely that the cells expressed enzymatic fingerprints adapted to high organic carbon concentrations. Protease activity varied over 1 order of magnitude (between $42.65 \pm 3.79$ and 427. $29 \pm 16.29$ amol cell $^{-1} \mathrm{~h}^{-1} ;$ Fig. 2), although specific activity of bacteria that used to grow in a rich medium $\left(\mathrm{d}_{\mathrm{exp}}\right)$ was lower than the one tested after several days of growth in a poor one $\left(\mathrm{d}_{\mathrm{fin}}\right)(122.00 \pm 132.33$ and $219.11 \pm 168.95 \mathrm{amol}$ cell $^{-1} \mathrm{~h}^{-1}$, respectively). Since protease activity is inhibited or unaffected by the presence of low molecular weight substrate (Donachie et al., 2001), is likely that the high concentration of readily accessible peptides in the rich medium (ZB/5) suppressed the cell-specific protease expression, while the complex nature of natural organic matter in the 'poor' medium (i.e., natural DOC), enhanced the proteolytic activity. The shift of the degradative fingerprint of 3 out of the 7 tested isolates between the two time points (Fig. 3), partly confirm this hypothesis. Indeed, the nMDS plot highlighted a consistent change in the degradation pattern of isolates $\mathrm{AG}$ and $\mathrm{AK}$, which were identified as strongly proteolytic in the 'poor' medium (Figs. 2 and 3) whereas in the rich medium their specific proteolytic activity was ten-fold lower $(44.78 \pm 1.49$ and $23.40 \pm 1.71 \mathrm{amol} \mathrm{cell}^{-1} \mathrm{~h}^{-1}$, respectively; Supplementary Fig. 1). The same pattern was evident for isolate 9_2 (Fig. 3 ), which almost doubled its cell-specific AMA activity in the 'poor' medium $(27.61 \pm 0.40$ and $58.42 \pm 0.42 \mathrm{amol}$ cell $^{-1} \mathrm{~h}^{-1}$ for rich and 'poor' media, respectively, Supplementary Fig. 1 and Fig. 2). These results agree with those reported by Baltar et al. (2017), which found a tight coupling between AMA activity and the complexity of organic matter supplied to the microbial community. While highlighting a certain degree of phenotypic plasticity for a subset of the tested isolates, the pattern showed by the nMDS plot (Fig. 3) also suggests that some of the bacterial isolates (i.e., 20_1, AF, 16_1_1 and 21) are genetically 'constrained' to express a specific set of exoenzymes. It has been hypothesized that members of peculiar environments, like the high-latitude pelagic microbial community, may have streamlined their hydrolytic machinery, specializing in the degradation of those substrate that they are more likely to encounter (Arnosti, 2014). This could be the case of isolates 16_1_1 and 21, which expressed the same hydrolytic pattern growing in both culture media (Fig. 3). Noteworthy, these two isolates expressed the highest cell-specific glycolytic activity, 1 order of magnitude higher than the other bacterial isolates (Fig. 2). Looking at the two growth conditions, glycolytic activity was, on average, faster in the rich medium relative to the 'poor' one (22.43 \pm 20.74 and $10.24 \pm 15.30 \mathrm{amol} \mathrm{cell}^{-1} \mathrm{~h}^{-1}$, respectively) as a consequence of the different concentration of substrates in the two media. In fact, polysaccharide hydrolysis is generally reported as substrate-inducible (Sinsabaugh and Follstad Shah, 2012) and the ZoBell medium is richer in organic carbon (an in this case in polysaccharides, derived by the yeast extract; Sommer, 1996) than natural seawater.

These two strains showed the highest contribution of dissolved extracellular enzymes to the total specific hydrolytic activity, among the tested isolates (up to $100 \%$, Fig. 3). The active release of cell-free extracellular enzymes has been linked, among several other factors, to the response of marine bacteria to starvation (Albertson et al., 1990). However, bacteria growing in the 'poor' medium experienced natural DOC concentration $(1.48 \mathrm{mg}$ $\mathrm{L}^{-1}$ ), thus cell starvation was unlikely to occur. More likely, the enhanced contribution of the dissolved exoenzymatic fraction to the total cell-specific activity might be linked to the lifestyle of the tested bacterial isolates. Indeed, the phylogenetic analysis identified the selected bacteria as members of the classes Flavobacteriia and $\gamma$ - 
Proteobacteria (Fig. 1), which are often found associated with particles (DeLong et al., 1993; Teeling et al., 2012; Crespo et al., 2013). Modelling, experimental and field studies suggest that the production of dissolved exoenzymes could be advantageous to particle-attached bacteria (Vetter et al., 1998; Vetter and Deming, 1999; Ziervogel and Arnosti, 2008). All our isolates expressed cell-free hydrolytic activity at $\mathrm{d}_{\text {fin }}$ (Fig. 2), although the contribution to total cell-specific activity varied greatly $(0-100 \%$, Fig. 2). This pattern may derive from the appropriate substrate stimulation exerted by the natural DOC supplied with the 'poor' medium (Alderkamp et al., 2007). Another possible explanation is that the isolates expressing the highest cellfree enzymatic activity (i.e., AG, 16_1_1 and 21, Fig. 2), have the genetic potential to produce dissolved extracellular enzymes even when not attached to detrital particles. There are indications that the fate of an extracellular enzyme (i.e., to be cell-bound or cell-free) could be genetically predetermined (Nguyen et al., 2019); thus, isolates expressing high cell-free exoenzymatic activity without the presence of particles could be viewed as 'climax' colonizers, extremely streamlined to take advantage of organic matter hot spots.

Given the expression of a conspicuous amount of cellfree extracellular enzymes in these isolates, we tested the hypothesis that the dissolved exoenzymatic activity may be enhanced by the presence of phytodetrital particles. For this test, one fast-growing bacterium, AG, identified as Halomonas meridiana (Fig. 1), was chosen. Halomonas meridiana is a halotolerant, mesophilic, Gram-negative bacterium, first isolated from Antarctic hypersaline lakes (James et al., 1990). This species shows some adaptation to exploit particles as organic matter hotspots, such as flagellar motility, and the ability to produce metalloproteases, required for the functioning of adhesion or detachment mechanisms (Anithajothi et al., 2014). Our results show that the contribution of the dissolved fraction to the total specific activity was always higher in tubes bearing particles and attached bacteria (PART, Tab. 2), confirming our initial hypothesis. The difference between SUR and PART tubes was already evident after $3 \mathrm{~h}$ from the tubes splitting for both BGLU and AMA (Tab. 2), albeit reducing over time. The reduced contribution of cellfree exoenzymes to total activity at t6 may be the result of the degradation of already present cell-free enzymes (i.e., produced during the colonization ad settling phases, see section 'Methods'), as these are themselves subjected to proteolytic hydrolysis (Ziervogel and Arnosti, 2008). The phytodetritus used for the experimental amendment was mainly composed of diatoms species ( $\sim 80 \%$ of total microplankton on the net sample; F. Cerino, personal communication), an important source of polysaccharides in the marine environment (Ziervogel and Arnosti, 2008; Alldredge et al., 1993). Nevertheless, glycolytic activity was extremely low ( $<2$ amol cell ${ }^{-1} \mathrm{~h}^{-1}$, Tab. 2$)$ during our experiment, with values very similar to those measured during the first experiment (Fig. 2). Recent studies highlight the existence of an alternative polysaccharide uptake mechanism in marine bacteria (Reintjes et al., 2017, 2019), suggesting that the use of simple model substrates (such as the one utilized in fluorometric assays) to assess glycolytic rates may be partially ineffective, especially when dealing with algal-derived, complex polysaccharides. The tested isolate, $\mathrm{AG}$, also showed similar pattern of AMA activity in SUR tubes and when cultured in the 'poor' media, remarkably modulating proteolytic activity when exposed to phytodetrital particles. Indeed, cell-specific hydrolysis rates in PART tubes were $\sim 50 \%$ lower than the rates measured both in SUR tubes and expressed in its enzymatic profiles, with an enhanced contribution of cell-free AMA activity in particle-enriched treatments (up to $23 \%$ ), suggesting a fine regulation of the degrative machinery according to the environmental conditions.

\section{CONCLUSIONS}

The results here presented showed that even closelyrelated bacterial isolates express different exoenzymatic profiles, and that the enzymatic fingerprint of an isolate may vary consistently according to the quality and quantity of the organic matter supplied as substrate for growth. Moreover, we added a piece of evidence on the mechanisms regulating cell-free exoenzymatic activity, demonstrating that bacteria growing associated with phytodetrital particles are more prone to actively release dissolved extracellular enzymes. By investigating the 'mise en place' of the microbial hydrolytic machinery under different environmental stimuli, this work deepens the current knowledge of the factors driving the organic matter hydrolysis in the ocean, the rate-limiting step of the marine carbon cycle. The continuation of these experimental activities, testing the response of different bacterial isolates to different substrates, will help to determine the conditions under which different hydrolysis patterns develop, deepening the current knowledge on the organic matter cycling in the ocean.

\section{ACKNOWLEDGEMENTS}

This study was carried out as part of the Italian Program for Research in Antarctica (PNRA) with funds from the project PRIAMO (PRokaryotes Interactions with Antarctic phytodetritus: a Micro- to macroscale voyage from the surface to the deep Ocean), PNRA16_00103. The constructive comments of F. Malfatti about the experimental designs and those of two anonymous reviewers are greatly acknowledged. 
Corresponding author: mcelussi@inogs.it

Key words: Organic matter hydrolysis; extracellular enzymatic activity; cell-free enzymes; particle-associated bacteria; free-living bacteria.

Received: 17 April 2019.

Accepted: 18 June 2019.

This work is licensed under a Creative Commons Attribution NonCommercial 4.0 License (CC BY-NC 4.0).

${ }^{\circ}$ Copyright: the Author(s), 2019

Licensee PAGEPress, Italy

Advances in Oceanography and Limnology, 2019; 10:8240

DOI: 10.4081/aiol.2019.8240

\section{REFERENCES}

Albertson NH, Nystrom T, Kjelleberg S, 1990. Exoprotease activity of two marine bacteria during starvation. Appl. Environ. Microbiol. 56;218-223.

Alderkamp AC, Van Rijssel M, Bolhuis H, 2007. Characterization of marine bacteria and the activity of their enzyme systems involved in degradation of the algal storage glucan laminarin. FEMS Microbiol. Ecol. 59:108-117.

Alldredge AL, Passow U, Logan BE. 1993. The abundance and significance of a class of large, transparent organic particles in the ocean. Deep-Sea Res. I 40:1131-1140.

Altschul SF, Gish W, Miller W, Myers EW, Lipman DJ, 1990. Basic local alignment search tool. J. Mol. Biol. 215:403-410.

Anithajothi R, Nagarani N, Umagowsalya G, Duraikannu K, Ramakritinan CM, 2014. Screening, isolation and characterization of protease producing moderately halophilic microorganism Halomonas meridiana associated with coral mucus. Toxicol. Environ. Chem. 96:296-306.

Arnosti,C. 2011. Microbial Extracellular Enzymes and the Marine Carbon Cycle. Ann. Rev. Mar. Sci. 3:401-425.

Arnosti C, 2014. Patterns of microbially driven carbon cycling in the ocean: Links between extracellular enzymes and microbial communities. Adv. Oceanogr. 2014:1-12.

Azam F, Malfatti F, 2007. Microbial structuring of marine ecosystems. Nat. Rev. Microbiol. 5:782-791.

Baltar F, Arístegui J, Gasol JM, Yokokawa T, Herndl GJ, 2013. Bacterial versus archaeal origin of extracellular enzymatic activity in the Northeast Atlantic deep waters. Microb. Ecol. 65:277-288.

Baltar F, Morán XAG, Lønborg C, 2017. Warming and organic matter sources impact the proportion of dissolved to total activities in marine extracellular enzymatic rates. Biogeochemistry 133:307-316.

Benner R, Amon RMW, 2015. The size-reactivity continuum of major bioelements in the ocean. Ann. Rev. Mar. Sci. 7:185-205.

Bidle KD, Azam F, 1999. Accelerated dissolution of diatom silica by marine bacterial assemblages. Nature 397:508-512.

Catalano G, Budillon G, La Ferla R, Povero P, Ravaioli M, Saggiomo V, Accornero A, Azzaro M, Carrada GC, Giglio F, Langone L, Mangoni O, Misic C, Modigh M, 2010. The Ross
Sea, p. 303-318. In: L. Liu, K.-K. Atkinson, L. Quinones and R. Talaue-McManus (eds.), Carbon and nutrient fluxes in continental margins: A global synthesis. Springer, New York.

Celussi M, Balestra C, Fabbro C, Crevatin E, Cataletto B, Fonda Umani S, Del Negro P, 2008. Organic-matter degradative potential of Halomonas glaciei isolated from frazil ice in the Ross Sea (Antarctica). FEMS Microbiol. Ecol. 65:504-512.

Celussi M, Cataletto B, Fonda Umani S, Del Negro P, 2009. Depth profiles of bacterioplankton assemblages and their activities in the Ross Sea. Deep-Sea Res. I Oceanogr. Res. Pap. 56:2193-2205.

Celussi M, Quero GM, Zoccarato L, Franzo A, Corinaldesi C, Rastelli E, Lo Martire M, Galand PE, Ghiglione JF, Chiggiato J, Coluccelli A, Russo A, Pallavicini A, Fonda Umani S, Del Negro P, Luna GM, 2018. Planktonic prokaryote and protist communities in a submarine canyon system in the Ligurian Sea (NW Mediterranean). Prog. Oceanogr. 168:210-221.

Clarke KR, Warwick RM, 1994. Similarity-based testing for community pattern: the two-way layout with no replication. Mar. Biol. 118:167-176.

Crespo BG, Pommier T, Fernández-Gómez B, Pedrós-Alió C, 2013. Taxonomic composition of the particle-attached and free-living bacterial assemblages in the Northwest Mediterranean Sea analyzed by pyrosequencing of the $16 \mathrm{~S}$ rRNA. Microbiologyopen 2:541-552.

Del Negro P, Celussi M, De Vittor C, Fonda Umani S, 2018. Rapid acclimation of microbes to changing substrate pools in epipelagic waters of an Antarctic polynya during austral summer 2003. Polar Biol. 41:1.

DeLong EF, Franks DG, Alldredge AL, 1993. Phylogenetic diversity of aggregate-attached vs. free-living marine bacterial assemblages. Limnol. Oceanogr. 38:924-934.

Dereeper A, Guignon V, Blanc G, Audic S, Buffet S, Chevenet F, Dufayard J-F, Guindon S, Lefort V, Lescot M, Claverie J-M, Gascuel O, 2008. Phylogeny.fr: robust phylogenetic analysis for the non-specialist. Nucleic Acids Res. 36:465-9.

Donachie SP, Christian JR, Karl DM, 2001. Nutrient regulation of bacterial production and ectoenzyme activities in the subtropical North Pacific Ocean. Deep-Sea Res. II 48:17191732.

Ducklow H, Steinberg D, Buesseler K, 2001. Upper ocean carbon export and the biological pump. Oceanography 14:50-58.

Giering SLC, Sanders R, Lampitt RS, Anderson TR, Tamburini C, Boutrif M, Zubkov MV, Marsay CM, Henson SA, Saw K, Cook K, Mayor DJ, 2014. Reconciliation of the carbon budget in the ocean's twilight zone. Nature 507:480-483.

Hansell D, Carlson C, Repeta D, Schlitzer R, 2009. Dissolved organic matter in the ocean: A controversy stimulates new insights. Oceanography 22:202-211.

Hassanshahian M, Zeynalipour MS, Musa FH, 2014. Isolation and characterization of crude oil degrading bacteria from the Persian Gulf (Khorramshahr provenance). Mar. Pollut. Bull. $82: 39-44$.

Hoarfrost A, Snider R, Arnosti C, 2017. Improved measurement of extracellular enzymatic activities in subsurface sediments using competitive desorption treatment. Front. Earth Sci. 5:13. doi: 10.3389/feart.2017.000135.

Hoppe HG, 1993. Use of fluorogenic model substrates for extracellular enzyme activity (EEA) measurement of bacteria, 
p. 423-431. In: P.F. Kemp, B.F. Sherr, E.B. Sherr and J.J. Cole (eds.), Handbook of methods in aquatic microbial ecology. CRC Press, Boca Raton.

Hoppe HG, Arnosti C, Herndl G, 2002. Ecological significance of bacterial enzymes in the marine environment, p. 73-107. In: R.G. Burns and R.P. Dick (eds.), Enzymes in the environment. activity, ecology, and applications. Marcel Dekker, New York.

Hoppe HG, Ullrich S, 1999. Profiles of ectoenzymes in the Indian Ocean: Phenomena of phosphatase activity in the mesopelagic zone. Aquat. Microb. Ecol. 19:139-148.

James SR, Dobson SJ, Franzmann PD, McMeekin TA, 1990. Halomonas meridiana, a new species of extremely halotolerant bacteria isolated from Antarctic saline lakes. Syst. Appl. Microbiol. 13:270-278.

Letunic I, Bork P, 2016. Interactive tree of life (iTOL) v3: an online tool for the display and annotation of phylogenetic and other trees. Nucleic Acids Res. 44:242-245.

Lo Giudice A, Fani R, 2015. Cold-adapted bacteria from a coastal area of the Ross Sea (Terra Nova Bay, Antarctica): linking microbial ecology to biotechnology. Hydrobiologia 761:417-441.

Lorenzen C, Jeffrey S, 1980. Determination of chlorophyll in seawater. Unesco Technical Paper in Marine Science no. 35. Unesco, Paris: 20 pp.

Malfatti F, Lee C, Tinta T, Pendergraft MA, Celussi M, Zhou Y, Sultana CM, Rotter A, Axson JL, Collins DB, Santander MV, Anides Morales AL, Aluwihare LI, Riemer N, Grassian VH, Azam F, Prather KA, 2019. Detection of active microbial enzymes in nascent sea spray aerosol: Implications for atmospheric chemistry and climate. Environ. Sci. Technol. Lett. 6:171-177.

Marie D, Brussaard CPD, Thyrhaug R, Bratbak G, Vaulot D, 1999. Enumeration of marine viruses in culture and natural samples by flow cytometry. Appl. Environ. Microbiol. $65 ; 45-52$.

Martinez J, Smith DC, Steward GF, Azam F, 1996. Variability in ectohydrolytic enzyme activities of pelagic marine bacteria and its significance for substrate processing in the sea. Aquat. Microb. Ecol. 10:223-230.

Misic C, Castellano M, Fabiano M, Ruggieri N, Saggiomo V, Povero P, 2006. Ectoenzymatic activity in surface waters: A transect from the Mediterranean Sea across the Indian Ocean to Australia. Deep-Sea Res. I 53:1517-1532.

Nguyen TT, Myrold DD, Mueller RS, 2019. Distributions of extracellular peptidases across prokaryotic genomes reflect phylogeny and habitat. Front. Microbiol. 10:413.

Nigam PS, 2013. Microbial enzymes with special characteristics for biotechnological applications. Biomolecules 3:597-611.

Oksanen J, 2017. Vegan: ecological diversity. R Package. Version 2.4-4.
Quast C, Pruesse E, Yilmaz P, Gerken J, Schweer T, Yarza P, Peplies J, Glöckner FO, 2013. The SILVA ribosomal RNA gene database project: Improved data processing and webbased tools. Nucleic Acids Res. 41:D590-D596.

R Development Core Team, 2018. R: A Language and environment for statistical computing Vienna, Austria.

Reintjes G, Arnosti C, Fuchs BM, Amann R, 2017. An alternative polysaccharide uptake mechanism of marine bacteria. ISME J. 11;1640-1650.

Reintjes G, Arnosti C, Fuchs B, Amann R, 2019. Selfish, sharing and scavenging bacteria in the Atlantic Ocean: a biogeographical study of bacterial substrate utilisation. ISME J. 13:1119-1132.

Sinsabaugh RL, Follstad Shah JJ. 2012. Ecoenzymatic stoichiometry and ecological theory. Annu. Rev. Ecol. Evol. Syst. 43:313-343.

Sommer R, 1996. Yeast extracts: production, properties and components. Proceedings 9th Int. Symp. on Yeasts, Sydney, Australia.

Stocker R. 2012. Marine microbes see a sea of gradients. Science 338:628-633.

Teeling H, Fuchs BM, Becher D, Klockow C, Gardebrecht A, Bennke CM, Kassabgy M, Huang S, Mann AJ, Waldmann J, Weber M, Klindworth A, Otto A, Lange J, Bernhardt J, Reinsch C, Hecker M, Peplies J, Bockelmann FD, Callies U, Gerdts G, Wichels A, Wiltshire KH, Glöckner FO, Schweder T, Amann R, 2012. Substrate-controlled succession of marine bacterioplankton populations induced by a phytoplankton bloom. Science 336:608-611.

Traving SJ, Thygesen UH, Riemann L, Stedmon A, 2015. A model of extracellular enzymes in free-living microbes: Which strategy pays off? Appl. Environ. Microbiol. 81:7385-7393.

Utermöhl H, 1958. [Zur Vervollkommung der quantitative Phytoplankton-Methodik].[Article in German]. Mitt. Internat. Ver. Limnol. 9:1-38.

Vetter YA, Deming JW, 1999. Growth rates of marine bacterial isolates on particulate organic substrates solubilized by freely released extracellular enzymes. Microb. Ecol. 37:86-94.

Vetter YA, Deming JW, Jumars PA, Krieger-Brockett BB, 1998. A predictive model of bacterial foraging by means of freely released extracellular enzymes. Microb. Ecol. 36:75-92.

Yoshida S, Hiraga K, Takehana T, Taniguchi I, Yamaji H, Maeda Y, Toyohara K, Miyamoto K, Kimura Y, Oda K, 2016. A bacterium that degrades and assimilates poly(ethyleneterephthalate). Science 351:1196-9.

Ziervogel K, Arnosti C, 2008. Polysaccharide hydrolysis in aggregates and free enzyme activity in aggregate-free seawater from the north-eastern Gulf of Mexico. Environ. Microbiol. 10:289-299. 